\title{
Clinical utility of next-generation sequencing in neurodevelopmental disorders: non-syndromic intellectual disability as a model
}

\author{
Nörogelişimsel hastalıklarda yeni nesil dizilemenin klinik kullanımı: \\ Model olarak sendromik olmayan zeka geriliği
}

\author{
Ahmet Okay Çağlayan \\ Division of Medical Genetics, Department of Medical Biology and Genetics, İstanbul Bilim University, İstanbul, Turkey
}

\begin{abstract}
Intellectual disability (ID) refers to a diverse group of disorders with marked heterogeneity in both clinical presentation and genetic etiology. Some cases of ID are associated with distinctive clinical findings that can lead to specific clinical and molecular diagnoses. However, sporadic cases of ID also occur in which the molecular pathogenesis cannot be identified via clinical diagnosis, and the genetic etiology is often unknown. New genomic technologies such as whole-exome sequencing, in which selective sequencing of all protein-coding genomic regions is performed, have proved to be the most efficient and cost-effective approach for identifying disease-causing variants in neurodevelopmental disorders, even in small nuclear families. Successful gene discovery efforts will lead to an improved understanding of the cellular and molecular mechanisms underpinning cases of individuals diagnosed with neurodevelopmental disorders, will inform screening programs and will promote the development of novel and more effective pharmacotherapies of personalized approaches to medical management.

Keywords: Intellectual disability; next-generation sequencing; novel gene identification.
\end{abstract}

$\ddot{O Z Z}$

Zeka geriliği hem klinik hem de genetik etyoloji olarak çeşitlilik gösteren geniş bir hastalık grubunu içerir. Zeka geriliği olan bazı hastalar spesifik klinik ve moleküler tanı konulmasına yardımcı olabilecek hastalığa özgü klinik bulgular gösterir. Bu tür özel klinik bulgular ile birlikte seyretmeyen zeka geriliğinde ise moleküler bozukluk klinik tanı ile ayırt edilemez ve genetik etyoloji sıklıkla bilinmemektedir. Tüm ekzom dizileme gibi genomun protein kodlayan tüm bölgelerinin dizilenmesini sağlayan yeni nesil genomik teknolojiler, nörogelişimsel hastalıklarda, çekirdek ailelerde bile hastalık nedeni olan mutasyonların bulunmasında en verimli ve uygun maliyetli yöntem olduklarını kanıtlamışlardır. Başarılı gen keşfi çalışmaları nörogelişimsel hastalıklı bireylerde altta yatan hücresel ve moleküler mekanizmaların anlaşılmasına yardımcı olacak, tarama programlarına bilgi aktaracak ve hastaların tıbbi bakımlarında hastaya özgü yeni ve daha etkili ilaç tedavilerine olanak sağlayacaktır.

Anahtar sözcükler: Zeka geriliği; yeni nesil dizileme; yeni gen tespiti.

Intellectual developmental disorder or intellectual disability (ID) is a neurodevelopmental disorder that is defined as an overall intelligence quotient of lower than 70 , is associated with functional deficits in adaptive behavior, social skills and communication, and has an onset age of 18 years or younger. ${ }^{[1]}$ Although, ID affects $1-3 \%$ of the general population. ${ }^{[2,3]}$ and represents one of the main reasons for referral in clinical genetic practices, it has not received as much public attention as other common neurodevelopmental diseases such as autism. ${ }^{[4]}$ Intellectual disability can be caused by environmental and/or genetic factors. ${ }^{[5-9]}$ Beyond the financial challenges, caring for a dependent with ID can have substantial social and emotional effects on a family and society. ${ }^{[10-13]}$ Knowledge regarding the genetic cause of ID allows for the anticipation and treatment of associated clinical symptoms, provides information on prognosis, and prevents further superfluous and often costly testing. Additionally, it allows for the identification of 
specific treatment options or dietary guidelines and supports the testing of additional family members to determine genotyping status so that reproductive counseling may be obtained.

Unfortunately, the genetic cause of most cases of ID remains unknown. ${ }^{[14]}$ Genetic causes of ID are thought to be present in 15-50\% of cases, ${ }^{[15-20]}$ although this number increases proportionally with severity. ${ }^{[2,21-24]}$ Most severe forms of ID are due to chromosomal abnormalities or defects in specific genes. It has been shown that approximately 15\% of ID cases are caused by visible cytogenetic anomalies (aneuploidies, gross deletions, inversions and rearrangements), ${ }^{[25]}$ and $\sim 15-20 \%$ are due to submicroscopic aberrations and pathogenic copy number variants. ${ }^{[25-32]} \mathrm{X}$-linked forms are estimated to account for only 5-10\% of ID cases ${ }^{[33]}$ which means that the vast majority of the underlying genetic defects remain elusive and are likely to be autosomal. ${ }^{[22,25]}$ In total, approximately 2,500 genes are estimated to be involved in monogenic causes of ID. ${ }^{[34]}$ The latest observations based on a parent-proband trio analysis to identify de novo changes in known or candidate genes for ID suggested that a significant portion of sporadic cases may be due to dominant de novo mutations. ${ }^{[35-39]}$ More recently, Hamdan et al. ${ }^{[40]}$ suggested that de novo mutations are the predominant cause of moderate or severe ID, on the basis of results from 41 cases of high-depth trio-based exome sequencing in patients with ID.

While autosomal recessive intellectual disability (AR-ID) is less prevalent, estimates of the contribution of recessive mutations to ID are as high as $25 \%$, and the majority have been characterized in consanguineous families. ${ }^{[41]}$ The marriage of second cousins or closer relatives, defined as consanguineous marriage, ${ }^{[42]}$ is still common in many parts of the world, particularly in the Middle East and Asia. ${ }^{[43]}$ In Turkey, the prevalence of consanguineous marriages has been quite high and stable in the last three decades at approximately 20-25\% (ranges from 11.5\% to $46 \%){ }^{[44-46]}$ The children of consanguineous individuals will have more homozygous DNA than the offspring of an outbred marriage. This leads to an increased likelihood of rare, recessive, disease-causing variants being inherited from both parents. On average, first cousins have an additional risk of $1.7-2.8 \%$ of having a child with an autosomal recessive disorder. ${ }^{[47]}$ The frequency of autosomal recessive, non-specific ID is unknown. The broad genetic heterogeneity of AR-ID, which usually non-syndromic nature, and the few reported cases (most genes were detected in single kindreds) make it difficult to determine consistent genotype-phenotype correlations.

The traditional genetic testing approach for AR-ID is usually successful in identifying new genes. ${ }^{[48-57]}$ This approach typically starts with targeted disease testing for mutations in known genes and consists of conventional karyotyping, especially for mosaic detection or patients with a specific medical and familial history, exclusion of fragile-X syndrome and array-based comparative genomic hybridization testing, followed by genome-wide homozygosity mapping in large consanguineous families and linkage analysis and then sequencing of genes within suspect intervals. However, positional mapping strategies (i.e., linkage analysis and homozygosity mapping) have several important limitations, for example, disease-related mutations could reside in regions of homozygosity that are too small to detect via traditional methods, particularly in probands from third cousin matings or often identify very large regions that contain hundreds of genes; and selecting relevant candidate genes can be problematic.

Whole-exome sequencing is a cost-effective and fast strategy for comprehensive mutation screening and disease-gene identification in the coding portion of the human genome. ${ }^{[58-60]}$ Because it is estimated that $80 \%$ of the variants that cause Mendelian disease are located within the exome, and approximately 15\% of suspected Mendelian diseases have a recessive mode of inheritance, the introduction of next-generation sequencing techniques has led to the discovery of a rapidly increasing number of autosomal recessive nonsyndromic ID causative genes. This situation makes whole-exome sequencing an attractive method for investigating rare genetic variants with large effects. ${ }^{[61,62]}$ In addition to mutations in TECR, ${ }^{[63]}$ MAN1B1, ${ }^{[64,65]}$ and ST3GAL3, ${ }^{[66]} 50$ putative novel autosomal recessive non-syndromic ID causative genes have been reported by Najmabadi et al. ${ }^{[65]}$ However, even after next generation sequencing (NGS) testing, many patients still do not have a molecular diagnosis. For example, two large studies on the genetics of ID using whole-exome 
sequencing provided a yield of $16-55 \% .^{[38,67]}$ There may be several explanations for this finding, such as technical limitations including insufficient coverage; trinucleotide repeat expansions or lowlevel mosaicism, which might be responsible for the clinical symptoms; etiologic mutations that may be located in noncoding regions; or large genomic events may occur. Alternatively, whole-genome sequencing is considered to be the most comprehensive form of genetic testing currently available. ${ }^{[68]}$ More recently, Glissen et al. ${ }^{[69]}$ performed whole-genome sequencing on 50 patients with severe ID and their unaffected parents with an average genome-wide coverage of 80 -fold, and a diagnosis was made in $42 \%$ of the patients. Whole genome sequencing is also not without its limitations, such as the fact that not all areas of the genome may be captured and analyzed, the control datasets for non-coding variants are less mature and still expensive than the whole-exome sequencing.

Numerous challenges are inherent in the identification of rare and common variants that have a role in IDs. One such challenge is the interpretation of pathogenic variants, including those derived from well-known disease-causing genes. ${ }^{[70]}$ Further functional testing should be performed on novel gene variants with the aim of enhancing our understanding of the molecular basis of the disease. ${ }^{[60,71-77]}$ Increased knowledge of the genetic and cellular mechanisms that cause ID could lead to the development of novel treatment options (Figure 1).

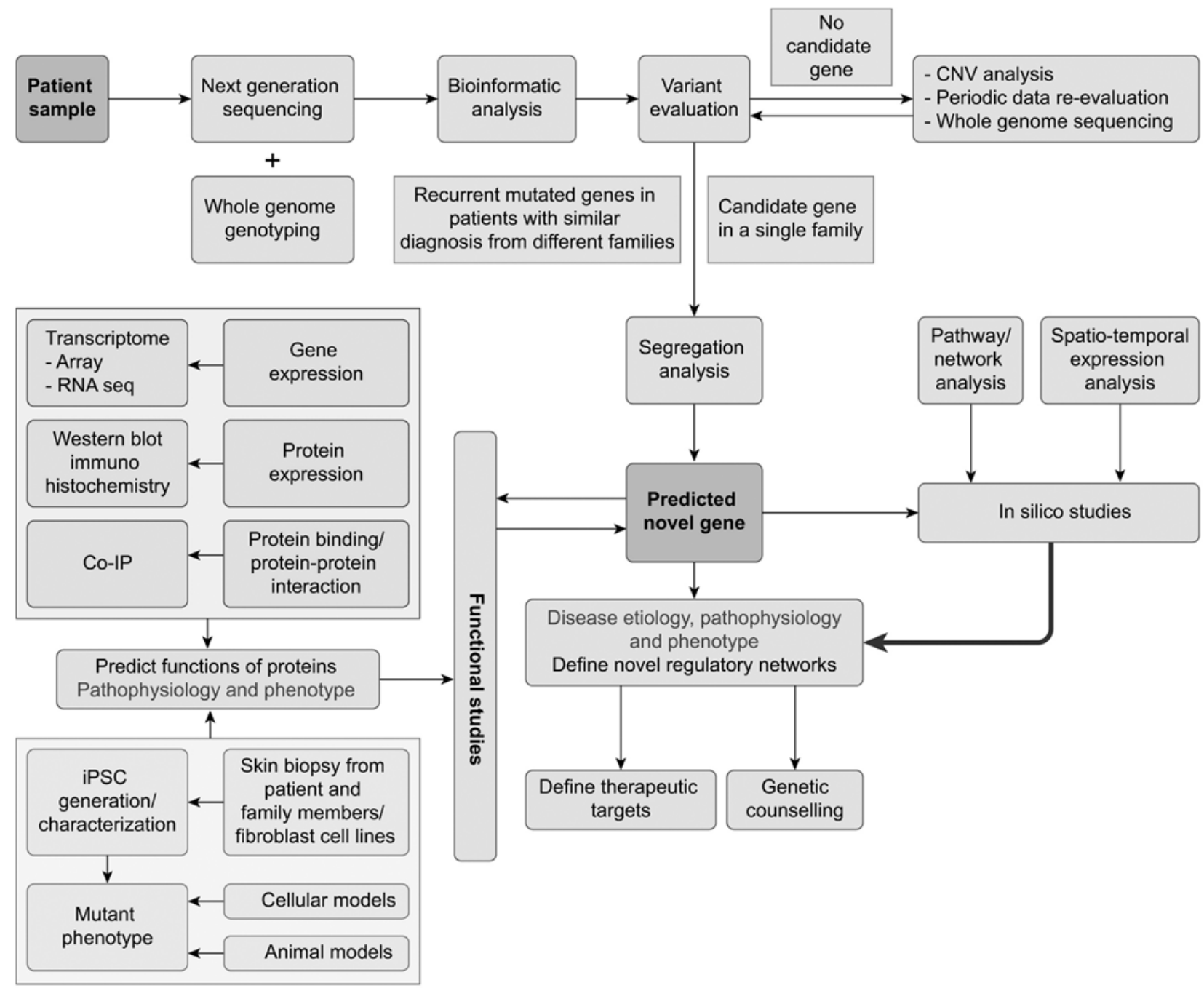

Figure 1. Novel gene identification steps in a patient with intellectual disability. A systemic approach is used to identify candidate variants and determine their pathogenicity. 
Regardless of advances in molecular technology, the currently identified mutated genes are responsible for only a small fraction of nonsyndromic ID cases and the remaining diseasecausing genes have not yet been identified.

\section{Declaration of conflicting interests}

The authors declared no conflicts of interest with respect to the authorship and/or publication of this article.

\section{Funding}

The authors received no financial support for the research and/or authorship of this article.

\section{REFERENCES}

1. Association AP. Disorders usually first diagnosed in infancy, childhood, or adolescence. In: DSMIV, diagnostic criteria. Washington: WA: American Psychiatric Association; 1994. p. 39-46.

2. Leonard $\mathrm{H}$, Wen $\mathrm{X}$. The epidemiology of mental retardation: challenges and opportunities in the new millennium. Ment Retard Dev Disabil Res Rev 2002;8:117-34.

3. Roeleveld N, Zielhuis GA, Gabreëls F. The prevalence of mental retardation: a critical review of recent literature. Dev Med Child Neurol 1997;39:125-32.

4. Salvador-Carulla L, Bertelli M. 'Mental retardation' or 'intellectual disability': time for a conceptual change. Psychopathology 2008;41:10-6.

5. Leonard H, Wen X. The epidemiology of mental retardation: challenges and opportunities in the new millennium. Ment Retard Dev Disabil Res Rev 2002;8:117-34.

6. Salvador-Carulla L, Reed GM, Vaez-Azizi LM, Cooper SA, Martinez-Leal R, Bertelli M, et al. Intellectual developmental disorders: towards a new name, definition and framework for "mental retardation/ intellectual disability" in ICD-11. World Psychiatry 2011;10:175-80.

7. Roeleveld N, Zielhuis GA, Gabreëls F. The prevalence of mental retardation: a critical review of recent literature. Dev Med Child Neurol 1997;39:125-32.

8. Maulik PK, Mascarenhas MN, Mathers CD, Dua T, Saxena S. Prevalence of intellectual disability: a metaanalysis of population-based studies. Res Dev Disabil 2011;32:419-36.

9. Winnepenninckx B, Rooms L, Kooy RF. Mental retardation: A review of the genetic causes. Brit J Dev Disabil 2003;49:29-44.

10. Picker JD, Walsh CA. New innovations: therapeutic opportunities for intellectual disabilities. Ann Neurol 2013;74:382-90.

11. Centers for Disease Control and Prevention (CDC). Economic costs associated with mental retardation, cerebral palsy, hearing loss, and vision impairment--
United States, 2003. MMWR Morb Mortal Wkly Rep 2004;53:57-9.

12. Polder JJ, Meerding WJ, Bonneux L, van der Maas PJ. Healthcare costs of intellectual disability in the Netherlands: a cost-of-illness perspective. J Intellect Disabil Res 2002;46:168-78.

13. Schwartz C, Tsumi A. Parental involvement in the residential care of persons with intellectual disability: The impact of parents' and residents' characteristics and the process of relocation. J Appl Res Intellect 2003;16:285-93.

14. Madrigal I, Alvarez-Mora MI, Karlberg O, RodríguezRevenga L, Elurbe DM, Rabionet $\mathrm{R}$, et al. Efficient application of next-generation sequencing for the diagnosis of rare genetic syndromes. J Clin Pathol 2014;67:1099-103.

15. Kaufman L, Ayub M, Vincent JB. The genetic basis of non-syndromic intellectual disability: a review. J Neurodev Disord 2010;2:182-209.

16. Shashi V, McConkie-Rosell A, Rosell B, Schoch $\mathrm{K}$, Vellore $\mathrm{K}, \mathrm{McD}$ nald $\mathrm{M}$, et al. The utility of the traditional medical genetics diagnostic evaluation in the context of next-generation sequencing for undiagnosed genetic disorders. Genet Med 2014;16:176-82.

17. Karam SM, Riegel M, Segal SL, Félix TM, Barros AJ, Santos IS, et al. Genetic causes of intellectual disability in a birth cohort: A population-based study. Am J Med Genet A 2015;167:1204-14.

18. Hunter AG. Outcome of the routine assessment of patients with mental retardation in a genetics clinic. Am J Med Genet 2000;90:60-8.

19. Chelly J, Khelfaoui M, Francis F, Chérif B, Bienvenu T. Genetics and pathophysiology of mental retardation. Eur J Hum Genet 2006;14:701-13.

20. Moeschler JB, Shevell M. Clinical genetic evaluation of the child with mental retardation or developmental delays. Pediatrics 2006;117:2304-16.

21. McLaren J, Bryson SE. Review of recent epidemiological studies of mental retardation: prevalence, associated disorders, and etiology. Am J Ment Retard 1987;92:243-54.

22. Ropers HH. Genetics of early onset cognitive impairment. Annu Rev Genomics Hum Genet 2010;11:161-87.

23. McLaren J, Bryson SE. Review of recent epidemiological studies of mental retardation: prevalence, associated disorders, and etiology. Am J Ment Retard 1987;92:243-54.

24. Mefford HC, Batshaw ML, Hoffman EP. Genomics, intellectual disability, and autism. $\mathrm{N}$ Engl $\mathrm{J}$ Med 2012;366:733-43.

25. Rauch A, Hoyer J, Guth S, Zweier C, Kraus $\mathrm{C}$, Becker $\mathrm{C}$, et al. Diagnostic yield of various genetic approaches in patients with unexplained developmental delay or mental retardation. Am J Med Genet A 2006;140:2063-74.

26. Zahir F, Friedman JM. The impact of array genomic hybridization on mental retardation research: a review 
of current technologies and their clinical utility. Clin Genet 2007;72:271-87.

27. Koolen DA, Pfundt R, de Leeuw N, Hehir-Kwa JY, Nillesen WM, Neefs I, et al. Genomic microarrays in mental retardation: a practical workflow for diagnostic applications. Hum Mutat 2009;30:283-92.

28. Battaglia A, Doccini V, Bernardini L, Novelli A, Loddo S, Capalbo A, et al. Confirmation of chromosomal microarray as a first-tier clinical diagnostic test for individuals with developmental delay, intellectual disability, autism spectrum disorders and dysmorphic features. Eur J Paediatr Neurol 2013;17:589-99.

29. Siggberg L, Ala-Mello S, Jaakkola E, Kuusinen $\mathrm{E}$, Schuit R, Kohlhase J, et al. Array CGH in molecular diagnosis of mental retardation - A study of 150 Finnish patients. Am J Med Genet A 2010;152:1398-410.

30. Cooper GM, Coe BP, Girirajan S, Rosenfeld JA, $\mathrm{Vu} \mathrm{TH}$, Baker $\mathrm{C}$, et al. A copy number variation morbidity map of developmental delay. Nat Genet 2011;43:838-46.

31. Miller DT, Adam MP, Aradhya S, Biesecker LG, Brothman AR, Carter NP, et al. Consensus statement: chromosomal microarray is a first-tier clinical diagnostic test for individuals with developmental disabilities or congenital anomalies. Am J Hum Genet 2010;86:749-64.

32. Hochstenbach $\mathrm{R}$, van Binsbergen E, Engelen J, Nieuwint A, Polstra A, Poddighe P, et al. Array analysis and karyotyping: workflow consequences based on a retrospective study of 36,325 patients with idiopathic developmental delay in the Netherlands. Eur J Med Genet 2009;52:161-9.

33. Lubs HA, Stevenson RE, Schwartz CE. Fragile X and X-linked intellectual disability: four decades of discovery. Am J Hum Genet 2012;90:579-90.

34. Kleefstra T, Schenck A, Kramer JM, van Bokhoven $\mathrm{H}$. The genetics of cognitive epigenetics. Neuropharmacology 2014;80:83-94.

35. Hamdan FF, Gauthier J, Araki Y, Lin DT, Yoshizawa $\mathrm{Y}$, Higashi $\mathrm{K}$, et al. Excess of de novo deleterious mutations in genes associated with glutamatergic systems in nonsyndromic intellectual disability. Am J Hum Genet 2011;88:306-16.

36. Sisodiya S. A de novo paradigm for mental retardation. J Med Genet 2011;48:S31.

37. Vissers LE, de Ligt J, Gilissen C, Janssen I, Steehouwer $\mathrm{M}$, de Vries $\mathrm{P}$, et al. A de novo paradigm for mental retardation. Nat Genet 2010;42:1109-12.

38. Rauch A, Wieczorek D, Graf E, Wieland T, Endele $\mathrm{S}$, Schwarzmayr T, et al. Range of genetic mutations associated with severe non-syndromic sporadic intellectual disability: an exome sequencing study. Lancet 2012;380:1674-82.

39. de Ligt J, Willemsen $\mathrm{MH}$, van Bon BW, Kleefstra $\mathrm{T}$, Yntema HG, Kroes $\mathrm{T}$, et al. Diagnostic exome sequencing in persons with severe intellectual disability. N Engl J Med 2012;367:1921-9.
40. Hamdan FF, Srour M, Capo-Chichi JM, Daoud $\mathrm{H}$, Nassif C, Patry L, et al. De novo mutations in moderate or severe intellectual disability. PLoS Genet 2014;10:1004772

41. Schuurs-Hoeijmakers JH, Vulto-van Silfhout AT, Vissers LE, van de Vondervoort II, van Bon BW, de Ligt $\mathrm{J}$, et al. Identification of pathogenic gene variants in small families with intellectually disabled siblings by exome sequencing. J Med Genet 2013;50:802-11.

42. Bittles A. Consanguinity and its relevance to clinical genetics. Clin Genet 2001;60:89-98.

43. Romeo G, Bittles AH. Consanguinity in the contemporary world. Hum Hered 2014;77:6-9.

44. Alper OM, Erengin H, Manguoğlu AE, Bilgen T, Cetin $\mathrm{Z}$, Dedeoğlu N, et al. Consanguineous marriages in the province of Antalya, Turkey. Ann Genet 2004;47:129-38.

45. Erdem Y, Tekşen F. Genetic screening services provided in Turkey. J Genet Couns 2013;22:858-64.

46. Tunçbilek E, Ozgüç M. Application of medical genetics in Turkey. Turk J Pediatr 2007;49:353-9.

47. Hamamy $\mathrm{H}$, Antonarakis SE, Cavalli-Sforza LL, Temtamy S, Romeo G, Kate LP, et al. Consanguineous marriages, pearls and perils: Geneva International Consanguinity Workshop Report. Genet Med 2011;13:841-7.

48. Molinari F, Rio M, Meskenaite V, Encha-Razavi $\mathrm{F}$, Augé J, Bacq D, et al. Truncating neurotrypsin mutation in autosomal recessive nonsyndromic mental retardation. Science 2002;298:1779-81.

49. Higgins JJ, Pucilowska J, Lombardi RQ, Rooney JP. A mutation in a novel ATP-dependent Lon protease gene in a kindred with mild mental retardation. Neurology 2004;63:1927-31.

50. Basel-Vanagaite L, Attia R, Yahav M, Ferland RJ, Anteki L, Walsh CA, et al. The CC2D1A, a member of a new gene family with C2 domains, is involved in autosomal recessive non-syndromic mental retardation. J Med Genet 2006;43:203-10.

51. Motazacker MM, Rost BR, Hucho T, Garshasbi M, Kahrizi K, Ullmann R, et al. A defect in the ionotropic glutamate receptor 6 gene (GRIK2) is associated with autosomal recessive mental retardation. Am J Hum Genet 2007;81:792-8.

52. Garshasbi M, Hadavi V, Habibi H, Kahrizi K, Kariminejad R, Behjati F, et al. A defect in the TUSC3 gene is associated with autosomal recessive mental retardation. Am J Hum Genet 2008;82:1158-64.

53. Molinari F, Foulquier F, Tarpey PS, Morelle W, Boissel $\mathrm{S}$, Teague J, et al. Oligosaccharyltransferase-subunit mutations in nonsyndromic mental retardation. Am J Hum Genet 2008;82:1150-7.

54. Mir A, Kaufman L, Noor A, Motazacker MM, Jamil T, Azam M, et al. Identification of mutations in TRAPPC9, which encodes the NIK- and IKKbeta-binding protein, in nonsyndromic autosomalrecessive mental retardation. Am J Hum Genet 2009;85:909-15. 
55. Philippe O, Rio M, Carioux A, Plaza JM, Guigue P, Molinari $\mathrm{F}$, et al. Combination of linkage mapping and microarray-expression analysis identifies NF-kappaB signaling defect as a cause of autosomal-recessive mental retardation. Am J Hum Genet 2009;85:903-8.

56. $\mathrm{GH}$, Mahajnah $\mathrm{M}$, Hill AD, Basel-Vanagaite L, Gleason D, Hill RS, et al. A truncating mutation of TRAPPC9 is associated with autosomal-recessive intellectual disability and postnatal microcephaly. Am J Hum Genet 2009;85:897-902.

57. Abou Jamra R, Wohlfart S, Zweier M, Uebe S, Priebe L, Ekici A, et al. Homozygosity mapping in 64 Syrian consanguineous families with non-specific intellectual disability reveals 11 novel loci and high heterogeneity. Eur J Hum Genet 2011;19:1161-6.

58. Ng SB, Bigham AW, Buckingham KJ, Hannibal MC, McMillin MJ, Gildersleeve HI, et al. Exome sequencing identifies MLL2 mutations as a cause of Kabuki syndrome. Nat Genet 2010;42:790-3.

59. Ng SB, Buckingham KJ, Lee C, Bigham AW, Tabor $\mathrm{HK}$, Dent KM, et al. Exome sequencing identifies the cause of a mendelian disorder. Nat Genet 2010;42:30-5.

60. Bilgüvar K, Oztürk AK, Louvi A, Kwan KY, Choi M, Tatli B, et al. Whole-exome sequencing identifies recessive WDR62 mutations in severe brain malformations. Nature 2010;467:207-10.

61. Bonnefond A, Durand E, Sand O, De Graeve F, Gallina $\mathrm{S}$, Busiah $\mathrm{K}$, et al. Molecular diagnosis of neonatal diabetes mellitus using next-generation sequencing of the whole exome. PLoS One 2010;5:13630.

62. Bell CJ, Dinwiddie DL, Miller NA, Hateley SL, Ganusova EE, Mudge J, et al. Carrier testing for severe childhood recessive diseases by next-generation sequencing. Sci Transl Med 2011;3:654.

63. Çalışkan M, Chong JX, Uricchio L, Anderson R, Chen $\mathrm{P}$, Sougnez $\mathrm{C}$, et al. Exome sequencing reveals a novel mutation for autosomal recessive non-syndromic mental retardation in the TECR gene on chromosome 19p13. Hum Mol Genet 2011;20:1285-9.

64. Rafiq MA, Kuss AW, Puettmann L, Noor A, Ramiah A, Ali G, et al. Mutations in the alpha 1,2-mannosidase gene, MAN1B1, cause autosomal-recessive intellectual disability. Am J Hum Genet 2011;89:176-82.

65. Najmabadi $\mathrm{H}, \mathrm{Hu} \mathrm{H}$, Garshasbi M, Zemojtel T, Abedini SS, Chen W, et al. Deep sequencing reveals 50 novel genes for recessive cognitive disorders. Nature 2011;478:57-63.

66. Hu H, Eggers K, Chen W, Garshasbi M, Motazacker MM, Wrogemann $\mathrm{K}$, et al. ST3GAL3 mutations impair the development of higher cognitive functions.
Am J Hum Genet 2011;89:407-14.

67. de Ligt J, Willemsen $\mathrm{MH}$, van Bon BW, Kleefstra $\mathrm{T}$, Yntema HG, Kroes $\mathrm{T}$, et al. Diagnostic exome sequencing in persons with severe intellectual disability. N Engl J Med 2012;367:1921-9.

68. Lupski JR, Reid JG, Gonzaga-Jauregui C, Rio Deiros $\mathrm{D}$, Chen DC, Nazareth L, et al. Whole-genome sequencing in a patient with Charcot-Marie-Tooth neuropathy. N Engl J Med 2010;362:1181-91.

69. Gilissen C, Hehir-Kwa JY, Thung DT, van de Vorst $\mathrm{M}$, van Bon BW, Willemsen $\mathrm{MH}$, et al. Genome sequencing identifies major causes of severe intellectual disability. Nature 2014;511:344-7.

70. Foo JN, Liu JJ, Tan EK. Whole-genome and wholeexome sequencing in neurological diseases. Nat Rev Neurol 2012;8:508-17.

71. Bilguvar K, Tyagi NK, Ozkara C, Tuysuz B, Bakircioglu $\mathrm{M}$, Choi M, et al. Recessive loss of function of the neuronal ubiquitin hydrolase UCHL1 leads to earlyonset progressive neurodegeneration. Proc Natl Acad Sci U S A 2013;110:3489-94.

72. Schaffer AE, Eggens VR, Caglayan AO, Reuter MS, Scott E, Coufal NG, et al. CLP1 founder mutation links tRNA splicing and maturation to cerebellar development and neurodegeneration. Cell 2014;157:651-63.

73. Mishra-Gorur K, Çağlayan AO, Schaffer AE, Chabu $\mathrm{C}$, Henegariu $\mathrm{O}$, Vonhoff $\mathrm{F}$, et al. Mutations in KATNB1 cause complex cerebral malformations by disrupting asymmetrically dividing neural progenitors. Neuron 2014;84:1226-39.

74. Radmanesh F, Caglayan AO, Silhavy JL, Yilmaz C, Cantagrel V, Omar T, et al. Mutations in LAMB1 cause cobblestone brain malformation without muscular or ocular abnormalities. Am J Hum Genet 2013;92:468-74.

75. Caglayan AO, Baranoski JF, Aktar F, Han W, Tuysuz B, Guzel A, et al. Brain malformations associated with Knobloch syndrome--review of literature, expanding clinical spectrum, and identification of novel mutations. Pediatr Neurol 2014;51:806-13.

76. Caglayan AO, Comu S, Baranoski JF, Parman Y, Kaymakçalan H, Akgumus GT, et al. NGLY1 mutation causes neuromotor impairment, intellectual disability, and neuropathy. Eur J Med Genet 2015;58:39-43.

77. Novarino G, Fenstermaker AG, Zaki MS, Hofree M, Silhavy JL, Heiberg AD, et al. Exome sequencing links corticospinal motor neuron disease to common neurodegenerative disorders. Science 2014;343:506-11. 